\title{
Nazobiliyer drenaja bağlı akut böbrek yetmezliği gelişebilir mi?
}

\author{
Can acute renal failure occur due to nasobiliary drainage?
}

Erkin ÖZTAŞ, Nuretdin SUNA, Ufuk Barış KUZU, Orhan ÇOŞKUN, Bülent ÖDEMIş, Selçuk Dişi̇BEYAZ, Ertuğrul KAYAÇETIN

Turkiye Yüksek Ihtisas Eğitim ve Araştırma Hastanesi, Gastroenteroloji Kliniği, Ankara

Nazobiliyer drenaj başlıca; akut süpüratif kolanjit, safra yollarına açılmış kist hidatik, postoperatif safra kaçakları ve kolestaz ilişkili özellikle kaşıntı gibi semptomlarn giderilmesinde tercih edilen endoskopik drenaj metodlarndan biridir. Nazobiliyer drenajın çeșitli avantajlarının yanında, ișlem süresini uzatması, oral kaviteden nazal yola geçirirken nadir de olsa zedelenmeye sebep olması, uyumsuz hastalarda kateterin yerinden çıkması ve hastada rahatsızlık hissi oluşturması gibi dezavantajları söz konusudur. Ancak nazobiliyer drenaj nedeniyle akut böbrek yetmezliği gelişimi ile ilgili literatürde bir veri yoktur. Burada koledok distalde muhtemel malign darlık ön tanısı ile nazobiliyer drenaj konulup cerrahiye refere edilen ancak bu süreçte aşırı biliyer drenaj ilişkili akut böbrek yetmezliği gelişen olguyu sunuyoruz.

Anahtar kelimeler: Nazobiliyer drenaj, akut böbrek yetmezliği
Nasobiliary drainage, an endoscopic drainage method, is used mainly for the treatment of symptoms such as acute suppurative cholangitis, hydatid cyst rupture into the bile duct, postoperative biliary drainage, and pruritus associated with cholestasis. In addition to its various benefits, nasobiliary drainage has disadvantages, including prolongation of the procedure, damage while passing from the oral cavity to nasal route, though rare, dislocation of the catheter in incompatible patients, and patient discomfort. However, there is no previous report in the literature indicating the occurrence of acute renal failure due to nasobiliary drainage. In this report, we present a case who was referred to surgery after nasobiliary drainage placement due to a preliminary diagnosis of malignant narrowing in the distal choledochus; however, acute renal failure developed during the procedure because of excessive biliary drainage.

Key words: Nasobiliary drainage, acute renal failure

şiddetli kaşıntı ve kilo kaybı şikayetleri ile kliniğimize kabul edildi. Bilinen kronik hastalık öyküsü yoktu. Fizik muayenesinde cilt ikterikti ve palpasyonla batın sağ üst kadranında hafif hassasiyet mevcuttu. Laboratuvar incelemesinde; beyaz küre sayımı $8.800 \times 10^{3} / \mathrm{uL}$, hemoglobin: $13.6 \mathrm{gr} / \mathrm{dl}$, hemotokrit \%40, trombosit; 206.000, INR; 1.24, C-reaktif protein; $8 \mathrm{mg} / \mathrm{L}$ (0-5), sedimentasyon oranl; $38 \mathrm{~mm} / \mathrm{saat}$, aspartat aminotransferaz; $52 \mathrm{U} /(<40)$, alanin aminotransferaz; 48 U/L (<41), alkalen fosfataz; 346 U/L ( 40-130), gama glutamil transferaz; $105 \mathrm{U} / \mathrm{L}$ (8-61), total bilirubin; $26.2 \mathrm{mg} / \mathrm{dl}(<$ 1.2), direkt bilirubin; $21,2 \mathrm{mg} / \mathrm{dl}$ ( $<0.30$ ), üre; $26 \mathrm{mg} / \mathrm{dl}$ (1050) ve kreatinin: $0.84 \mathrm{mg} / \mathrm{dl}(0.5-1.2)$ idi. Transabdominal ultrasonografide safra yolları bilateral dilate idi, koledok en geniş yerinde $14 \mathrm{~mm}$ ölçüldü ve distalde künt sonlanıyordu. Abdomen bilgisayarl tomografi (BT) de ultrasonografi (USG) bulgularını doğrular nitelikteydi, koledok distalinde duvar kalınlaşması ve darlık söz konusu idi. Bu bulgularla hastaya ERCP yapıldı. ERCP'de papilla hacimli görünümdeydi ve alınan kolanjiogramda koledoğun distalde, suprapapiller lokalizasyonda künt sonlandığı görüldü. Hastaya endoskopik sfinkterotomi yapıldı, koledok distalinden biyopsiler alınarak 10 Fr plastik stent konuldu. Takip eden 10 günlük süreçte hastanın kolestaz parametrelerinde gerileme olmaması ve şiddetli kaşıntı şikayetinin devam etmesi nedeniyle tekrar ERCP yapıldı ve plastik stente ilave olarak sol intrahepatik safra yollarına uzanacak şekilde 7 Fr NBD kateteri konuldu.

Altmış dokuz yaşında kadın hasta bir ay önce başlayan sarılık, 


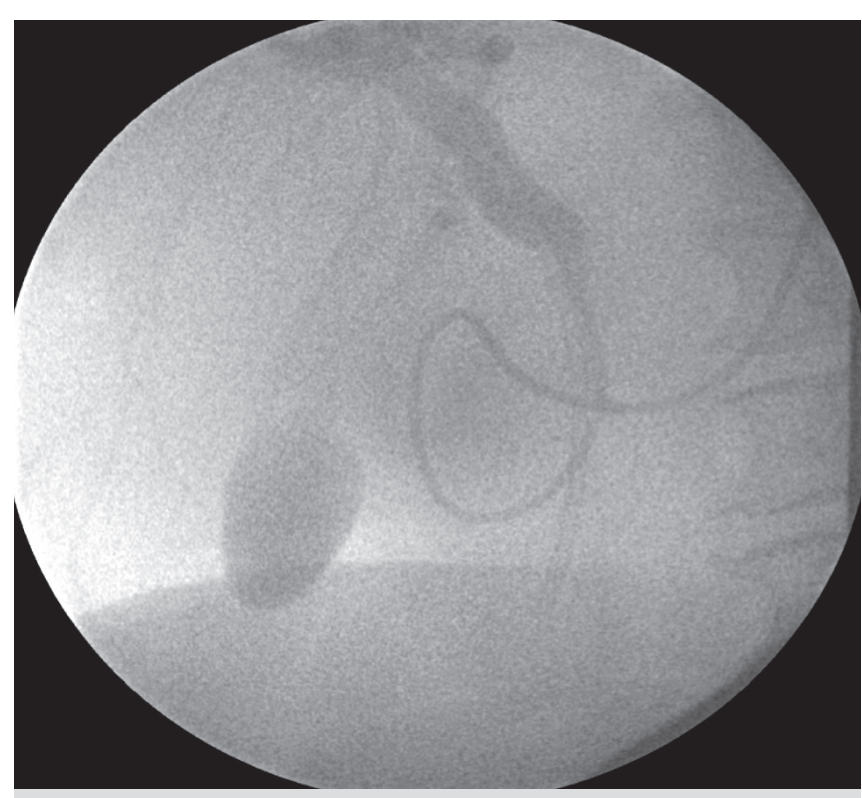

Resim 1. Kolanjiogramda NBD kateterinin yerinde olduğu görülmekle

Koledok distalinden alınan biyopsiler nonspesifik bulgular olarak rapor edildi. Bu bulgularla hasta operasyon önerisi ile cerrahiye başvurmak üzere taburcu edildi. Taburcu edildikten bir hafta sonra uykuya meyil ve şiddetli halsizlik nedeniyle tekrar kliniğimize başvuran hastanın fizik muayenesinde dehidratasyon bulguları söz konusu idi ve yapılan tetkiklerinde kolestaz parametrelerinde belirgin gerileme olmakla birlikte üre: $210 \mathrm{mg} / \mathrm{dl}$ (10-50), kreatinin: $6,9 \mathrm{mg} / \mathrm{dl}(0,5-1,2)$, sodyum: $142 \mathrm{mmol} / \mathrm{L}$ (136-145), potasyum: $5,7 \mathrm{mmol} / \mathrm{L}(3,5-$ $5,1)$ ve arteriyel kan gazında $\mathrm{pH}: 7,2(7,35-7,45)$ bulundu. Tam kan sayıminda hematokrit \%52 idi ve lökositoz yoktu. Taburculuğu sonrasında geçen bir haftalık süreçle ilgili kolanjit gelişimi açısından sorguland, kolanjit lehine semptom yoktu, nefrotoksik ilaç öyküsü sorgulandı, negatifti. Ciddi de-

\section{KAYNAKLAR}

1. Nagai N, Toki F, Oi I, et al. Continuous endoscopic pancreatocholedochal catheterization. Gastrointest Endosc 1976;23:78-81.

2. Sharma BC, Reddy RS, Garg V. Endoscopic management of hepatic hydatid cyst with biliary communication. Dig Endosc 2012;24:267-70.

3. Yang J, Peng JY, Pang EJ, Chen W. Efficacy of endoscopic nasobiliary drainage for the prevention of post-endoscopic retrograde cholangiopancreatography pancreatitis and cholangitis after repeated clearance of common bile duct stones: Experience from a Chinese center. Dig Endosc 2013;25:453-8

4. Horiuchi A, Nakayama Y, Kajiyama M, et al. Biliary stenting in the management of large or multiple common bile duct stones. Gastrointest Endosc 2010;71:1200-3.e2. hidratasyon bulgularını açılayacak diyare, sürekli kusma gibi semptomlar da yoktu. Üriner ultrasonografi ve renal vasküler yapıların doppler ile değerlendirmesinde aşikar patolojik bulguya rastlanmadı. Ancak hasta ve hasta yakınlarının ifadesine göre NBD kateteri konulduktan sonra günlük gelen miktar 2800-3400 cc arasında değişmişti. Hasta hospitalize edildikten sonra NBD takibinde günlük 3000 cc geleni olduğu görüldü. Tüm bu bulgularla aşırı nazobiliyer drenaj nedeniyle oral sıvı alımı da yeterli olmayan hastada prerenal azotemi ilişkili akut böbrek yetmezliği geliştiği düşünüldü. ERCP tekrarland,, kolanjiogramda NBD kateterinin yerinde olduğu görülmekle birlikte (Resim-1) NBD ve yine önceki işlemde yerleștirilmiş olan $10 \mathrm{Fr}$ plastik stent çıartıldı ve koledoğa tekrar $10 \mathrm{Fr}$ plastik stent yerleştirildi. Parenteral sıvı replasmanına rağmen üre ve kreatinin değerleri gerilemeyen ve metabolik asidozu derinleşen hastaya aralıklı olarak hemodiyaliz uygulandı. İkinci hospitalizasyonunun 10. gününden itibaren idrar çıkışı arttı, renal fonksiyonları tedrici olarak düzelmeye başladı. Renal fonksiyonları tamamen düzeldikten sonra cerrahiye sevk edildi

\section{TARTIŞMA}

Normalde karaciğerden duodenuma günlük 600 - $1200 \mathrm{ml}$ safra salınmaktadır (6). Bunun yanında olgumuzda olduğu gibi günlük nazobiliyer drenajın yaklaşı 3.5 litreye ulaşabileceği ile ilgili literatürde herhangi bir veriye rastlanmamıştır. NBD'ın en önemli dezavantajları kateterin yerinden çıkması ve hasta konforunu bozması olmakla birlikte olgumuz NBD konulan olguların drenaj açısından yakın takip edilmeleri gerektiğini ortaya koymaktadır. Bu olguda olduğu gibi drenaj miktarı beklenmedik derecede yüksek olabilir ve parenteral hidrasyon gerektirebilir. Enterasan bir şekilde, sıklıkla akut süpüratif kolanjit olgularında septik şok ve bununla ilişkili renal fonksiyon bozukluklarının düzeltilmesi amaçlı kullanılan NBD (7), olgumuzda olduğu gibi akut renal yetmezliğin sebebi olabilir.

5. Park DH, Kim MH, Lee SK, et al. Endoscopic sphincterotomy vs. endoscopic papillary balloon dilation for choledocholithiasis in patients with liver cirrhosis and coagulopathy. Gastrointest Endosc 2004;60:180-5.

6. Guyton AC, Hall JE. Textbook of Medical Physiology, WB Saunders Comp., USA, 2000.

7. 7. Lai ECS, Paterson IA, Tam PC, et al. Severe acutecholangitis: The role of emergency nasobiliarydrainage. Surgery 1990;107:268-72. 